\title{
PUSAT KULINER KHAS KABUPATEN HULU SUNGAI SELATAN DI BANJARMASIN
}

\author{
Fitria Arissa Yulandha \\ Program Studi Teknik Arsitektur Fakultas Teknik Universitas Lambung Mangkurat \\ Fitriaarissayulandha@gmail.com \\ Anna Oktaviana \\ Program Studi Teknik Arsitektur Fakultas Teknik Universitas Lambung Mangkurat \\ aoktaviana@unlam.ac.id
}

\begin{abstract}
ABSTRAK
Hulu Sungai Selatan memiliki kuliner khas daerah yang sangat menarik untuk dicicipi namun popularitas kekhasan kuliner Hulu Sungai Selatan ini kurang berkembang karena orang-orang dari berbagai daerah di luar Hulu Sungai Selatan tidak memiliki cukup banyak waktu atau kesempatan datang langsung ke Hulu Sungai Selatan. Saat ini kota yang menjadi tempat singgah atau menetap kebanyakan orang dari berbagai pulau, provinsi maupun kabupaten adalah kota Banjarmasin, di Banjarmasin sebenarnya sudah ada tempat yang menjual kuliner khas Hulu Sungai Selatan namun sayangnya sebagian besar hanya menjual ketupat kandangan saja sedangkan kuliner lainnya kurang di populerkan, dari hal tersebut muncul permasalahan yakni bagaimana merancang sebuah pusat kuliner yang dapat mempopulerkan kekhasan kuliner Hulu Sungai Selatan di Banjarmasin, Untuk menjawab permasalahan tersebut diperlukan sebuah desain pusat kuliner yang dapat menjadi media untuk mempopulerkan kuliner khas Hulu Sungai Selatan dengan menggunakan metode Atmospheres Peter Zumthor yang menekankan pengolahan interior dan eksterior pada desain dan menerapkan aspek-aspek desain dari Atmospheres Peter Zumthor itu sendiri sebagai konsep dari rancangan. Pada pusat kuliner ini hanya beberapa aspek saja yang diterapkan sebagai konsep pada desain interior dan eksterior hal ini menyesuaikan dengan kebutuhan pada pusat kuliner, bagian interior pusat kuliner ini menekankan aspek the body of architecture, material compatibility, the temperature of space, between composure and seduction, levels of intimacy dan the light on things pada area makan, dapur, galeri dan toko bahan kuliner sedangkan pada bagian eksterior menekankan aspek material compatibility, the temperature of space, surrounding objects, tension between interior \& exterior dan the light on things pada bagian luar bangunan dan tapak. Dengan demikian diharapkan nantinya pusat kuliner ini mampu menjadi media yang bisa mempopulerkan kekhasan kuliner Hulu Sungai Selatan.
\end{abstract}

Kata kunci: pusat kuliner, Hulu Sungai Selatan, Atmospheres

\begin{abstract}
Hulu Sungai Selatan has very interesting regional specialties to taste, but the popularity of the Hulu Sungai Selatan culinary specialty is less developed because people from various regions outside Hulu Sungai Selatan do not have enough time or opportunity to come directly to Hulu Sungai Selatan. At present the city that is a place to stay or settle is that most people from various islands, provinces and districts are Banjarmasin, in Banjarmasin there are actually places that sell typical Hulu Sungai Selatan culinary but unfortunately most only sell ketupat kandangan only while other cuisines are less popular, from that problem arises that is how to design a culinary center that can popularize the peculiarities of the Hulu Sungai Selatan culinary in Banjarmasin. To answer these problems a central culinary design can be used as a medium to popularize the typical Hulu Sungai Selatan culinary using the Peter Zumthor Atmospheres method emphasize the processing of the interior and exterior of the design and apply the design aspects of Peter Zumthor's Atmospheres themselves as a concept of design. At this culinary center only a few aspects are applied as concepts in interior and exterior design, this adjusts to the needs of the culinary center, the interior of the culinary center emphasizes the body of architecture aspects, material compatibility, between composure and seduction, levels of intimacy and the light on things in the dining, kitchen, gallery and culinary materials stores while on the exterior emphasizes compatibility, the temperature of the space, surrounding objects, tension between
\end{abstract}


interior \& exterior and the light on things on the outside buildings and sites. Thus, it is hoped that this culinary center will be able to become a media that can popularize the culinary specialties of Hulu Sungai Selatan.

Keywords: culinary center, South Hulu Sungai, Atmospheres

\section{PENDAHULUAN}

Indonesia merupakan Negara yang sangat kaya dengan keberagaman budaya dan kulinernya yang ada di setiap pulau yang tersebar di berbagai bagian wilayah Indonesia, salah satunya adalah pulau Kalimantan. Pulau Kalimantan terbagi atas lima Provinsi salah satunya adalah Provinsi Kalimantan Selatan dengan Banjarmasin sebagai ibu kota provinsi yang memiliki enam Kabupaten. Salah satu Kabupaten yang memiliki kekhasan tersendiri baik itu dari budaya maupun kulinernya adalah Kabupaten Hulu Sungai Selatan yang beribu kota Kandangan dengan luas 1.703 km2. Kuliner yang paling terkenal dan menjadi primadona di Hulu Sungai Selatan maupun di luar Hulu Sungai Selatan adalah ketupat kandangan. Namun selain ketupat kandangan Hulu Sungai Selatan juga memiliki kuliner lain seperti dodol kandangan, lamang, lupis, patah, cangkaruk, dan apam batil.

Tabel 1 Kuliner Khas Kabupaten Hulu Sungai Selatan

\begin{tabular}{|c|c|}
\hline Nama kuliner & Foto \\
\hline \multicolumn{2}{|l|}{ Ketupat kandangan } \\
\hline & $\begin{array}{l}\text { Gambar } 1 \text { Ketupat Kandangan } \\
\text { Sumber: dokumentasi dan survei }\end{array}$ \\
\hline \multirow[t]{2}{*}{ Dodol kandangan } & \\
\hline & $\begin{array}{l}\text { Gambar } 2 \text { Dodol kandangan } \\
\text { Sumber:Indonesiakaya.com }\end{array}$ \\
\hline \multirow[t]{2}{*}{ Lamang putih } & \\
\hline & $\begin{array}{l}\text { Gambar } 3 \text { Lamang putih } \\
\text { Sumber: dokumentasi dan survei }\end{array}$ \\
\hline \multirow[t]{2}{*}{ Lamang hirang } & \\
\hline & $\begin{array}{l}\text { Gambar } 4 \text { Lamang hirang } \\
\text { Sumber: www.indonesiakaya.com }\end{array}$ \\
\hline \multirow[t]{2}{*}{ Lupis } & \\
\hline & Gambar 5 Lupis \\
\hline
\end{tabular}

\begin{tabular}{|l|l|}
\hline Patah & Sumber: dokumentasi dan survei \\
\hline cangkaruk & Sumber: dokumentasi dan survei \\
\hline Apam batil & Sumber: dokumentasi dan survei \\
\hline
\end{tabular}

Sumber: Hj. Aty \& H. Alin

Keberagaman kuliner tersebut lebih banyak terdapat atau dijual di wilayah Kabupaten Hulu Sungai Selatan dengan ibu kota kandangan. Dari kota kandangan memerlukan jarak tempuh 116,4 km dengan waktu kurang lebih 3 jam perjalanan ke kota Banjarmasin yang saat ini menjadi kota yang biasa dijadikan tempat singgah atau menetap oleh banyak orang dari berbagai pulau, provinsi maupun kabupaten dengan jumlah penduduk sekitar 700.869 jiwa di tahun 2018 (Badan Pusat Statistik Provinsi Kalimantan Selatan). Jarak yang cukup jauh dan waktu yang cukup lama untuk mencapai kota kandangan tentunya menjadi kendala bagi orang-orang luar pulau, provinsi maupun kabupaten baik itu yang hanya singgah ataupun menetap di Banjarmasin untuk dapat secara langsung menikmati kekhasan kuliner Hulu Sungai Selatan karena tidak punya cukup banyak waktu atau tidak banyak kesempatan untuk datang ke Kandangan.

Di kota Banjarmasin sudah ada beberapa rumah makan atau warung makan yang mengenalkan kuliner khas Hulu Sungai Selatan namun sebagian besar hanya kuliner ketupat kandangan saja, sedangkan kuliner khas Hulu Sungai Selatan yang lainnya seperti dodol kandangan, Lamang, lupis, patah, cangkaruk, dan apam batil kurang dipopulerkan bahkan tidak ada di Banjarmasin. Berikut data rumah makan 
atau warung makan ketupat kandangan yang cukup dikenal di Banjarmasin.

Tabel 2 Warung Makan Ketupat Kandangan Di Banjarmasin

\begin{tabular}{|c|c|c|c|}
\hline Nama & Alamat & Fasilitas & Foto \\
\hline \multirow[t]{2}{*}{$\begin{array}{l}\text { Warung } \\
\text { Kaum } \\
\text { Ketupat } \\
\text { Kandangan }\end{array}$} & $\begin{array}{l}\text { Jl. Bumi Mars } \\
\text { Raya, } \\
\text { Pemurus } \\
\text { Baru, }\end{array}$ & $\begin{array}{l}\text { Area makan, } \\
\text { tempat } \\
\text { parkir motor }\end{array}$ & 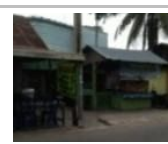 \\
\hline & $\begin{array}{l}\text { Banjarmasin } \\
\text { Sel }\end{array}$ & & $\begin{array}{l}\text { Gambar } 9 \\
\text { Warung } \\
\text { Kaum } \\
\text { Ketupat } \\
\text { Kandangan } \\
\text { Sumber: } \\
\text { dokumentas } \\
\text { i dan survei }\end{array}$ \\
\hline $\begin{array}{l}\text { Ketupat } \\
\text { Kandangan } \\
\text { Hj. Ida }\end{array}$ & $\begin{array}{l}\text { Jl. Kp. Melayu } \\
\text { Darat, } \\
\text { Banjarmasin }\end{array}$ & $\begin{array}{l}\text { Area makan, } \\
\text { tempat } \\
\text { parkir motor }\end{array}$ & sipming \\
\hline & Tengah & & $\begin{array}{l}\text { Gambar } 10 \\
\text { Ketupat } \\
\text { Kandangan } \\
\text { Hj. Ida } \\
\text { Sumber : } \\
\text { dokumentas } \\
\text { i dan survei }\end{array}$ \\
\hline $\begin{array}{l}\text { Ketupat } \\
\text { Kandangan } \\
\text { Hj Mursinah }\end{array}$ & $\begin{array}{l}\text { Jl. } \\
\text { Cendrawasih } \\
\text { No.7 RT. 29, } \\
\text { Belitung } \\
\text { Selatan, } \\
\text { Banjarmasin } \\
\text { Barat }\end{array}$ & $\begin{array}{l}\text { Area makan, } \\
\text { tempat } \\
\text { parkir motor }\end{array}$ & $\begin{array}{l}\text { Gambar } 11 \\
\text { Ketupat } \\
\text { Kandangan } \\
\text { Hj Mursinah } \\
\text { Sumber: } \\
\text { Google } \\
\text { maps }\end{array}$ \\
\hline
\end{tabular}

Sumber: Penulis

Dari data diatas warung makan menyediakan fasilitas utama berupa area makan ketupat kandangan dan fasilitas penunjang berupa area parkir, hal ini membuat pengunjung hanya dapat mencicipi ketupat kandangan saja dan tidak dapat mencicipi kuliner khas Hulu Sungai Selatan yang lainnya dalam satu tempat tersebut, selain itu pengunjung pun tidak dapat mengetahui bagaimana keunikan proses pembuatan atau pengolahan berbagai kuliner khas Hulu Sungai Selatan yang sebenarnya dapat menjadi strategi untuk menarik pengunjung sekaligus mengenalkan kekhasan kuliner Hulu Sungai Selatan.

Berdasarkan uraian diatas maka di rencanakanlah pusat kuliner khas Kabupaten Hulu Sungai Selatan di Banjarmasin yang bertujuan untuk mengenalkan dan mempopulerkan kekhasan kuliner Hulu Sungai Selatan kepada orang-orang yang datang dari luar pulau kalimantan, khususnya kepada orang-orang dari berbagai provinsi maupun Kabupaten yang singgah atau menetap di Banjarmasin berupa pusat kuliner khas Hulu Sungai Selatan yang dapat mempermudah orang-orang untuk mencicipi, mengetahui dan mengenal kuliner khas Hulu Sungai Selatan baik itu cita rasa kulinernya hingga proses pembuatannya. Untuk itu diperlukan pengolahan bagian dalam maupun luar pusat kuliner menggunakan metode atmospheres Peter Zumthor yang diharapkan nantinya pengunjung tidak hanya dimanjakan oleh cita rasa khas kuliner Hulu Sungai Selatan tetapi juga suasana dan nuansa yang tidak dapat ditemui di tempat lain sehingga pengunjung tertarik untuk datang lagi dan merekomendasikan pusat kuliner ini kepada orang lain, dengan demikian kuliner khas Hulu Sungai Selatan akan semakin terangkat dan populer. Metode atmospheres Peter Zumthor ini menekankan pada pengolahan bagian dalam maupun luar suatu bangunan agar memiliki atmosfer yang berbeda dan menjadi daya tarik tersendiri.

\section{PERMASALAHAN}

Bagaimana merancang pusat kuliner khas Hulu Sungai Selatan yang dapat mengenalkan dan mempopulerkan kekhasan dari kuliner Hulu Sungai Selatan di Banjarmasin dengan pendekatan menggunakan metode atmospheres Peter Zumthor dalam mengolah bagian dalam dan luar bangunan.

\section{TINJAUAN PUSTAKA}

\section{A. Pengertian Pusat Kuliner}

Pusat kuliner terdiri dari dua kata yakni pusat dan kuliner. Arti kata pusat yang terdapat di dalam Kamus Besar Bahasa Indonesia edisi Kedua (1994:801) adalah tempat yang letaknya berada di bagian tengah, pokok pangkal atau yang menjadi pumpunan (sebagai urusan hal dan sebagainya) sedangkan kata kuliner berasal dari bahasa inggris "culinary" artinya segala hal yang berhubungan dengan dapur serta masakan. Jadi pusat kuliner memiliki arti sebagai tempat yang menjadi pangkal atau pusat dari hal-hal yang berhubungan dengan segala masakan atau makanan. 


\section{B. Fungsi Pusat Kuliner}

Menurut Geoffrey Broadbent fungsi di dalam arsitektur berupa wadah untuk berbagai kegiatan (container of activities), dari hal tersebut fungsi dalam arsitektur secara fisik berarti merupakan sesuatu yang dapat mewadahi atau menampung segala aktivitas serta kegiatan tertentu sehingga dapat mendatangkan manfaat atau menghadirkan rasa nyaman dan aman untuk semua penggunanya.

Fungsi pusat kuliner khas Hulu Sungai Selatan ini adalah:

- Sebagai tempat jual beli produk kuliner khas Hulu Sungai Selatan.

- Sebagai tempat atau media untuk mengenalkan dan mempopulerkan kuliner khas Hulu Sungai Selatan.

\section{Kuliner Khas Hulu Sungai Selatan}

Berdasarkan hasil wawancara penulis dengan hj. Aty dan h. Alin orang yang mengerti dan tau cara membuat kuliner khas Hulu Sungai Selatan dapat dijelaskan satu persatu kuliner khas Hulu Sungai Selatan yakni sebagai berikut:

1. Ketupat Kandangan

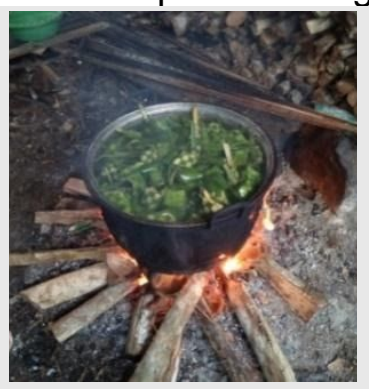

Gambar 12

Memasak Ketupat

Kandangan

Sumber:

dokumentasi dan survei

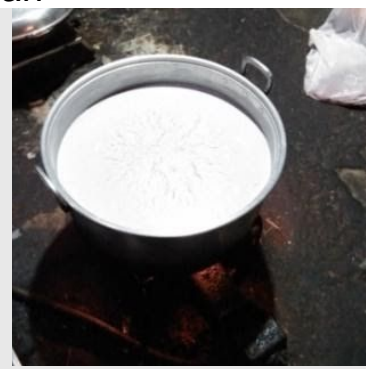

Gambar 13

Memasak Kuah

Ketupat Kandangan Sumber:

dokumentasi dan survei
Ketupat kandangan merupakan kuliner yang berasal dari kota Kandangan dan sangat terkenal di dalam maupun diluar kota Kandangan dan umumnya dimakan oleh orang-orang Kandangan untuk sarapan ataupun makan siang namun ada juga sebagian yang memakannya di malam hari sebagai menu makan malam. Ketupat kandangan yang berbahan dasar beras ini biasa disantap bersama dengan kuah santan yang didampingi dengan ikan haruan (ikan gabus), hintalu jaruk (telur asin) atau telur rebus. Uniknya ketupat kandangan ini biasanya disantap oleh orang-orang Kandangan dengan menggunakan tangan yakni dengan menghancurkan ketupat yang disajikan dengan jari tangan.

\section{Dodol Kandangan}

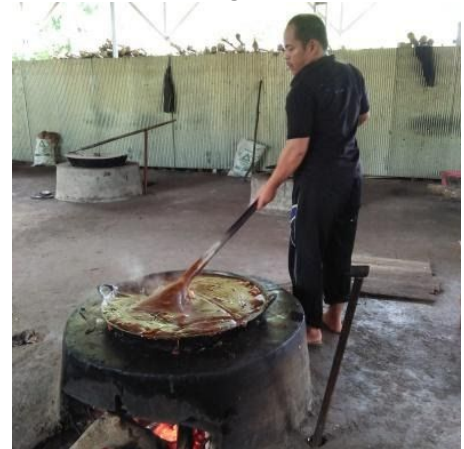

\section{Gambar 14 Memasak Dodol Kandangan} Sumber: dokumentasi dan survei

Dodol kandangan merupakan kue dari kota Kandangan yang enak dengan rasa manis dan teksturnya yang kenyal berbahan dasar tepung beras ketan dan gula aren, dodol kandangan biasanya tersedia dengan berbagai varian rasa diantaranya rasa kacang, kelapa, durian dan lain-lain yang seringkali dijadikan oleh-oleh. Dodol kandangan ini biasanya menjadi usaha turun-temurun dari generasi ke generasi dan biasa dijual pada kios-kios kecil di pinggir jalan desa Hamalau yang ada di Kandangan.

\section{Lamang}

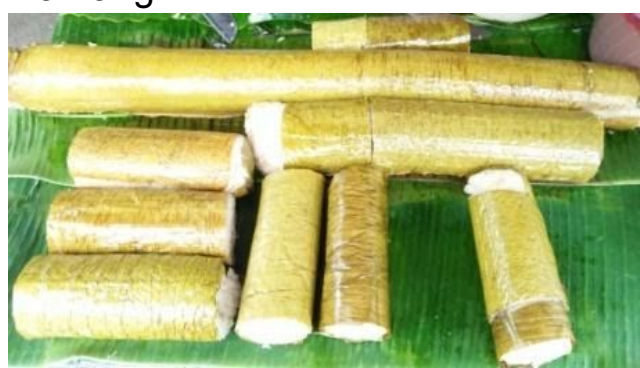

Gambar 15 Lamang

Sumber: dokumentasi dan survei

Lamang merupakan kue yang berbahan dasar beras ketan dan uniknya dimasak dalam seruas bambu yang dipanggang berdiri pada bara api yang terbuat dari sabut kelapa. Menurut kebiasaan orang Kandangan Lamang selalu hadir di berbagai 
acara selamatan (hajatan). Lamang ini memiliki dua varian yakni lamang putih yang terbuat dari beras ketan putih dan lamang hirang yang terbuat dari beras ketan hitam.

Untuk menikmati lamang ini ruas bambu harus dihentak-hentak terlebih dulu untuk mengeluarkan lamang dari dalam bambu atau bisa juga dengan membelah bambu menggunakan parang, lamang yang sudah keluar dari dalam bambu kemudian dipotong-potong untuk disajikan. Biasanya Lamang ini dimakan bersama dengan hintalu jaruk (telur asin), kijing (kerang), kacang, cancangan ayam (daging ayam yang dicincang) tempe dan sambal sate.

Tabel 3 Makanan Pendamping Lamang

\begin{tabular}{|c|c|c|}
\hline Nama & Keterangan & Foto \\
\hline Hintalu Jaruk & $\begin{array}{l}\text { Telur bebek yang } \\
\text { diawetkan dengan } \\
\text { cara diasinkan }\end{array}$ & $\begin{array}{l}\text { Gambar } 16 \text { Hintalu } \\
\text { Jaruk } \\
\text { Sumber: dokumentasi } \\
\text { dan survei }\end{array}$ \\
\hline kijing & $\begin{array}{lr}\text { Kerang } & \text { kecil yang } \\
\text { dioseng dengan } \\
\text { berbagai } & \text { macam } \\
\text { rempah } & \text { dan } \\
\text { bumbu, } & \text { ini } \\
\text { merupakan } & \\
\text { pendamping } & \\
\text { lamang yang hanya } \\
\text { ada kalau musiman }\end{array}$ & - \\
\hline Kacang & $\begin{array}{l}\text { Kacang kedelai yang } \\
\text { direbus dan } \\
\text { dicampur dengan } \\
\text { sambal karih }\end{array}$ & \\
\hline & & $\begin{array}{l}\text { Gambar } 17 \text { Kacang } \\
\text { Sumber: } \\
\text { dokumentasi dan } \\
\text { survei }\end{array}$ \\
\hline $\begin{array}{l}\text { Cancangan } \\
\text { Ayam }\end{array}$ & $\begin{array}{lr}\text { Daging } & \text { ayam } \\
\text { dicincang } & \text { dan } \\
\text { dimasak } & \text { bersama } \\
\text { dengan } & \text { sambal } \\
\text { habang } & \text { (bumbu } \\
\text { merah) } & \end{array}$ & 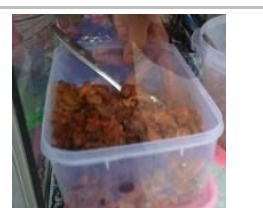 \\
\hline & & $\begin{array}{l}\text { Gambar } 18 \\
\text { Cancangan Ayam } \\
\text { Sumber: dokumentasi } \\
\text { dan survei }\end{array}$ \\
\hline Tempe & $\begin{array}{l}\text { Tempe yang } \\
\text { dipotong kecil-kecil }\end{array}$ & $\begin{array}{l}\text { Sambar } 19 \text { Tempe } \\
\text { Sumber: dokumentasi } \\
\text { dan survei }\end{array}$ \\
\hline
\end{tabular}

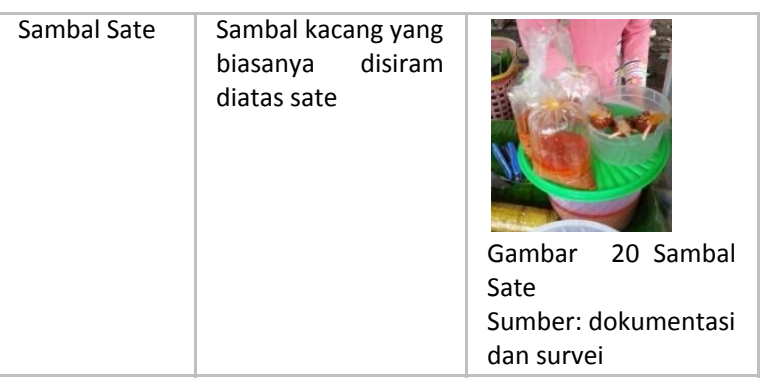

Sumber: Penulis

4. Lupis

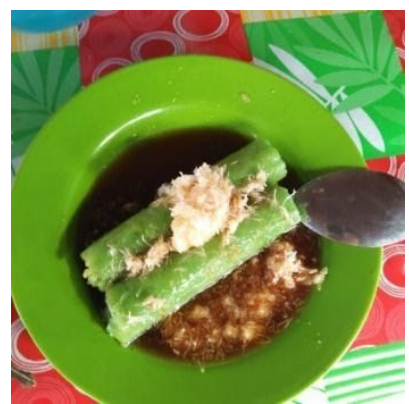

Gambar 21 Lupis

Sumber: dokumentasi dan survei

Lupis merupakan kue berbentuk bulat memanjang berwarna hijau dengan bahan dasar ketan, lupis ini dimakan bersama dengan parutan kelapa dan gula aren yang dilelehkan.

\section{Patah}

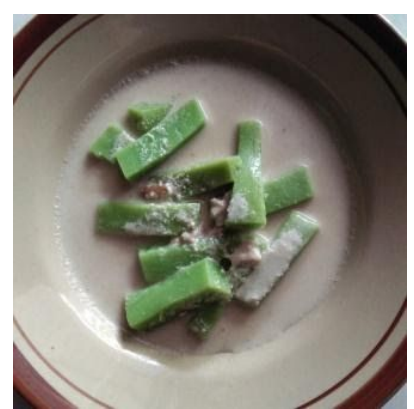

Gambar 22 Patah

Sumber: dokumentasi dan survei

Patah merupakan kue yang biasanya dijual bersama dengan lupis di dalam satu warung yang sama, patah ini berbahan dasar tepung beras yang dihidangkan bersama dengan kuah santan yang dicampur dengan daging ikan haruan (ikan gabus) yang haluskan.

6. Cangkaruk 


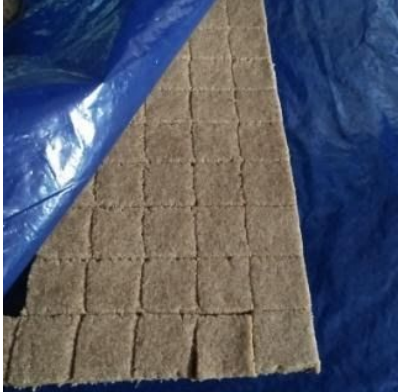

Gambar 23 Cangkaruk

Sumber: dokumentasi dan survei

Cangkaruk merupakan kue yang memiliki rasa manis sama seperti dodol kandangan, biasanya cangkaruk ini dijual berdampingan dengan dodol kandangan, cangkaruk ini berbahan dasar beras ketan yang disangrai dan ditumbuk dengan lesung.

\section{Apam Batil}

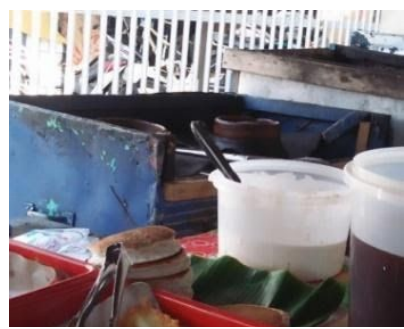

Gambar 24 Apam Batil

Sumber: dokumentasi dan survei

Apam batil yang memiliki cukup banyak penggemar ini berbahan dasar tepung beras. Uniknya untuk memasak apam batil ini orang kandangan biasanya menggunakan wajan yang sengaja dibelah menjadi beberapa bagian dan juga menggunakan penutup wajan yang terbuat dari tanah. Walaupun bisa disantap menggunakan sendok kebanyakan orang Kandangan menyantapnya menggunakan tangan. Apam batil ini dimakan bersama kuah dari gula aren yang dilelehkan yang dituangkan langsung diatas apam batil, apam batil ini biasanya dijual disatu warung yang sama dengan lupis dan patah.

\section{Jenis Kegiatan}

Secara umum kegiatan di dalam pusat kuliner adalah kegiatan makan namun berbeda halnya dengan pusat kuliner khas Hulu Sungai Selatan di Banjarmasin ini, untuk mempopulerkan kuliner khas Hulu Sungai Selatan pusat kuliner ini tidak hanya mewadahi kegiatan makan saja. Kegiatan pada pusat kuliner khas Hulu Sungai Selatan di Banjarmasin ini dibagi menjadi dua jenis kegiatan yakni:

\section{Kegiatan Utama}

Kegiatan utama di dalam pusat kuliner khas Hulu Sungai Selatan ini ada 2 yaitu kegiatan produksi ketupat kandangan dan penjualan kuliner khas Hulu Sungai Selatan seperti ketupat kandangan, dodol kandangan, lamang, lupis, patah, cangkaruk serta apam batil.

\section{Kegiatan Pendukung}

Kegiatan pendukung yang ada pada pusat kuliner khas Hulu Sungai Selatan ini yakni :

- Galeri sebagai wadah informasi yang menunjukkan serta menjelaskan cara pembuatan berbagai kuliner yang dijual dari awal hingga siap disajikan, hal ini merupakan upaya dalam memperkenalkan sekaligus mempopulerkan kuliner khas Hulu Sungai Selatan.

- Kegiatan penjualan bahan yang biasa digunakan untuk mengolah kuliner khas Hulu Sungai Selatan misalnya penjualan berbagai macam bahan dasar dan bahan pendukung lainnya yang sering digunakan untuk memasak kuliner khas Hulu Sungai Selatan seperti beras ketan, santan, gula aren, ikan haruan (ikan gabus), kelapa, daun kelapa, tempurung kelapa, ruas bambu, daun pisang dan lain-lain.

- Menikmati 2 jenis hiburan yang ada pada pusat kuliner khas Hulu Sungai Selatan yakni hiburan pertunjukkan dan hiburan permainan tradisional. berikut hiburan pertunjukkan dan permainan yang disuguhkan di pusat kuliner khas Hulu Sungai Selatan:

\begin{tabular}{|c|c|c|}
\hline \multicolumn{3}{|c|}{$\begin{array}{l}\text { Tabel } 4 \text { Pertunjukkan Pada Pusat Kulin } \\
\text { Khas Kabupaten Hulu Sungai Selatan }\end{array}$} \\
\hline Hiburan & Keterangan & Foto \\
\hline $\begin{array}{l}\text { Musik } \\
\text { panting }\end{array}$ & $\begin{array}{l}\text { Instrumen } \\
\text { musik yang } \\
\text { didominasi } \\
\text { alat musik } \\
\text { bernama } \\
\text { panting }\end{array}$ & $\begin{array}{l}\text { fic } \\
\text { Gambar } 25 \text { Musik Panting } \\
\text { Sumber: } \\
\text { https//www.kompasiana.com }\end{array}$ \\
\hline
\end{tabular}




\begin{tabular}{|c|c|c|}
\hline Madihin & $\begin{array}{l}\text { Seni } \\
\text { berpuisi } \\
\text { yang } \\
\text { mengandun } \\
\text { g } \\
\text { nasehat-na } \\
\text { sehat }\end{array}$ & $\begin{array}{l}\text { Gambar } 26 \text { Madihin } \\
\text { Sumber: } \\
\text { https://hasanzainuddin.wordpress. } \\
\text { com }\end{array}$ \\
\hline Lamut & $\begin{array}{l}\text { Seni } \\
\text { bercerita } \\
\text { yang } \\
\text { mengandun } \\
\text { g nilai atau } \\
\text { nasehat }\end{array}$ & $\begin{array}{l}\text { Gambar } 27 \text { Lamut } \\
\text { Sumber: https://id.m.wikipedia.org }\end{array}$ \\
\hline $\begin{array}{l}\text { Maman } \\
\text { da }\end{array}$ & $\begin{array}{l}\text { Seni } \\
\text { pementasa } \\
\mathrm{n} \\
\text { tradisional }\end{array}$ & $\begin{array}{l}\text { Gambar } 28 \text { Mamanda } \\
\text { Sumber: https://m.kbr.id }\end{array}$ \\
\hline
\end{tabular}

Sumber: Penulis

Tabel 5 Permainan Pada Pusat Kuliner Khas Kabupaten Hulu Sungai Selatan

\begin{tabular}{|c|c|c|}
\hline Hiburan & Keterangan & Foto \\
\hline Bapidak & $\begin{array}{l}\text { Dimainkan } \\
\text { minimal } 2 \\
\text { orang untuk } \\
\text { berlomba } \\
\text { memecahkan } \\
\text { biji pidak (biji } \\
\text { pohon karet) } \\
\text { lawan }\end{array}$ & $\begin{array}{l}\text { Gambar } 29 \text { Bapidak } \\
\text { Sumber: youtube habib A.R }\end{array}$ \\
\hline Balogo & $\begin{array}{l}\text { Dimainkan } \\
\text { minimal } 2 \\
\text { orang untuk } \\
\text { berlomba } \\
\text { menghancurka } \\
\mathrm{n} \text { susunan logo } \\
\text { (tempurung } \\
\text { kelapa) lawan }\end{array}$ & $\begin{array}{l}\text { Gambar } 30 \text { Balogo } \\
\text { Sumber: } \\
\text { https://mommyasia.id/4193 }\end{array}$ \\
\hline Badaku & $\begin{array}{l}\text { Dimainkan } 2 \\
\text { orang saja yang } \\
\text { saling } \\
\text { bergantian } \\
\text { memasukkan } \\
\text { batu atau } \\
\text { kerang pada } 16 \\
\text { lubang, yang } \\
\text { jadi pemenang } \\
\text { dalam } \\
\text { permainan ini } \\
\text { adalah yang } \\
\text { paling banyak } \\
\text { mengumpulkan } \\
\text { batu atau } \\
\text { kerang }\end{array}$ & $\begin{array}{l}\text { Gambar } 31 \text { Badaku } \\
\text { Sumber: } \\
\underline{\text { https://riauberbagi.blogspot.co }}\end{array}$ \\
\hline
\end{tabular}

Sumber: Penulis
- Beribadah, kegiatan beribadah ini lebih ditujukan untuk para pelaku yang beragama islam yang wajib sholat setiap harinya.

\section{E. Pelaku, Aktivitas dan Kebutuhan Ruang}

\section{Pemilik}

Pemilik merupakan orang yang memiliki pusat kuliner dan mengelola serta bertanggung jawab pada keperluan, kebutuhan, manajemen kegiatan dan administrasi maupun permasalahan di dalam pusat kuliner. Pemilik pusat kuliner ini ada 2 orang yakni $\mathrm{H}$. Alin dan $\mathrm{Hj}$. Aty dengan jam operasional mulai dari jam 11:00 sampai 21:00, berikut tabel aktivitas, pola aktivitas dan kebutuhan ruang pemilik

Tabel 6 Aktivitas, Pola Aktivitas dan Kebutuhan Ruang Pemilik

\begin{tabular}{|c|c|c|c|}
\hline $\begin{array}{l}\mathbf{N} \\
\mathbf{0}\end{array}$ & Aktivitas & Pola Aktivitas & $\begin{array}{l}\text { Kebutuhan } \\
\text { Ruang }\end{array}$ \\
\hline 1 & Datang & & Parkir, $\quad r$. \\
\hline 2 & Parkir & 3 & pemilik, \\
\hline 3 & $\begin{array}{l}\text { Mengambi } \\
\text { I uang }\end{array}$ & $1 \cdot 2 \cdot \frac{3}{4}$ & $\begin{array}{l}\text { ATM center, } \\
\text { dapur, area }\end{array}$ \\
\hline 4 & Ke ruangan & & pemesanan, \\
\hline 5 & $\begin{array}{l}\text { Mengawas } \\
\text { i seluruh } \\
\text { kegiatan }\end{array}$ & & $\begin{array}{l}\text { r. tunggu, } \\
\text { area makan, } \\
\text { kasir, }\end{array}$ \\
\hline 6 & Ishoma & & gudang \\
\hline 7 & Buang air & & bahan, \\
\hline 8 & Pulang & & $\begin{array}{l}\text { toko bahan } \\
\text { kuliner, } \\
\text { galeri, area } \\
\text { hiburan, } \\
\text { gudang, r. } \\
\text { genset, r. } \\
\text { pompa, } \\
\text { mushola } \\
\text { dan toilet }\end{array}$ \\
\hline
\end{tabular}

Sumber: Penulis

\section{Kasir}

Kasir merupakan orang yang menangani proses pembayaran yang ada di dalam pusat kuliner, kasir ini dibagi menjadi 2 sesuai penempatannya. Berikut pembagian kasir serta aktivitas, pola aktivitas dan kebutuhan ruang kasir:

\section{Tabel 7 Pembagian Kasir}

\begin{tabular}{|l|l|l|l|}
\hline Penempatan & Shift & $\begin{array}{l}\text { Jumlah } \\
\text { Orang }\end{array}$ & $\begin{array}{l}\text { Jam } \\
\text { Operasional }\end{array}$ \\
\hline Area makan & 1 & 1 & $11: 00-16: 00$ \\
\cline { 2 - 4 } & 2 & 1 & $16: 00-21: 00$ \\
\hline \multirow{2}{*}{$\begin{array}{l}\text { Penjualan bahan } \\
\text { mengolah kuliner }\end{array}$} & 1 & 2 & $11: 00-16: 00$ \\
\cline { 2 - 4 } & 2 & 2 & $16: 00-21: 00$ \\
\hline
\end{tabular}

Sumber: Penulis 
Tabel 8 Aktivitas, Pola Aktivitas dan Kebutuhan Ruang Kasir

\begin{tabular}{|c|c|c|c|c|}
\hline $\begin{array}{l}\mathbf{N} \\
\mathbf{O}\end{array}$ & Aktivitas & Pola Aktivitas & & $\begin{array}{l}\text { Kebutuhan } \\
\text { Ruang }\end{array}$ \\
\hline 1 & Datang & \multirow{9}{*}{$1 \cdot 2 \cdot \sqrt{3} \cdot \frac{4}{5} \cdot \sqrt{6}$} & \multirow{9}{*}{$\frac{7}{8} \cdot 2 \cdot$} & \multirow{9}{*}{$\begin{array}{l}\text { Parkir, } r \\
\text { loker, ATM } \\
\text { center, } \\
\text { kasir, area } \\
\text { makan, } \\
\text { toko bahan } \\
\text { kuliner, } \\
\text { mushola } \\
\text { dan toilet }\end{array}$} \\
\hline 2 & Parkir & & & \\
\hline 3 & Absen & & & \\
\hline 4 & $\begin{array}{l}\text { Mengamanka } \\
\mathrm{n} \text { barang }\end{array}$ & & & \\
\hline 5 & $\begin{array}{l}\text { Mengambil } \\
\text { uang }\end{array}$ & & & \\
\hline 6 & $\begin{array}{l}\text { Menjalankan } \\
\text { tugas }\end{array}$ & & & \\
\hline 7 & ishoma & & & \\
\hline 8 & Buang air & & & \\
\hline 9 & pulang & & & \\
\hline
\end{tabular}

\section{Pelayan}

Pelayan merupakan orang yang bertugas untuk melayani pengunjung dan pemilik dalam memproduksi ketupat kandangan. Pada pusat kuliner khas Hulu Sungai Selatan ini pelayan dibagi berdasarkan penempatannya.

\section{Tabel 9 Pembagian Pelayan}

\begin{tabular}{|c|c|c|c|c|}
\hline $\begin{array}{l}\text { Temp } \\
\text { at }\end{array}$ & Tugas & shift & $\begin{array}{l}\text { Jumlah } \\
\text { orang }\end{array}$ & $\begin{array}{l}\text { Jam } \\
\text { operasiona } \\
\text { | }\end{array}$ \\
\hline \multirow{8}{*}{ Dapur } & $\begin{array}{l}\text { Memanggang } \\
\text { ikan haruan } \\
\text { masak kuah } \\
\text { ketupat dan } \\
\text { memasak } \\
\text { ketupat }\end{array}$ & - & 3 & $\begin{array}{l}09: 00-11: 0 \\
0 \& \\
14: 00-16: 0 \\
0\end{array}$ \\
\hline & $\begin{array}{l}\text { Membantu } \\
\text { juru masak } \\
\text { untuk } \\
\text { menyiapkan } \\
\text { bahan } \\
\text { mengolah } \\
\text { ketupat } \\
\text { kandangan } \\
\text { dan } \\
\text { mengurus } \\
\text { bagian } \\
\text { gudang }\end{array}$ & - & 4 & $\begin{array}{l}08: 00-09: 0 \\
0 \& \\
13: 00-14: 0 \\
0\end{array}$ \\
\hline & \multirow{2}{*}{$\begin{array}{l}\text { Membersihka } \\
\mathrm{n} \text { peralatan } \\
\text { makan dan } \\
\text { masak }\end{array}$} & 1 & 3 & $\begin{array}{l}11: 00-16: 0 \\
0\end{array}$ \\
\hline & & 2 & 3 & $\begin{array}{l}16: 00-21: 0 \\
0\end{array}$ \\
\hline & \multirow{2}{*}{$\begin{array}{l}\text { Menyajikan } \\
\text { kuliner untuk } \\
\text { dihidangkan } \\
\text { ke } \\
\text { pengunjung }\end{array}$} & 1 & 6 & $\begin{array}{l}11: 00-16: 0 \\
0\end{array}$ \\
\hline & & 2 & 6 & $\begin{array}{l}16: 00-21: 0 \\
0\end{array}$ \\
\hline & \multirow[t]{2}{*}{$\begin{array}{l}\text { Membuat } \\
\text { minuman }\end{array}$} & 1 & 4 & $\begin{array}{l}11: 00-16: 0 \\
0\end{array}$ \\
\hline & & 2 & 4 & $\begin{array}{l}16: 00-21: 0 \\
0\end{array}$ \\
\hline
\end{tabular}

\begin{tabular}{|c|c|c|c|c|}
\hline \multirow[t]{2}{*}{$\begin{array}{l}\text { Area } \\
\text { maka } \\
\text { n }\end{array}$} & \multirow{2}{*}{$\begin{array}{l}\text { Menyambut } \\
\text { pengunjung, } \\
\text { menerima } \\
\text { pesanan, } \\
\text { memberikan } \\
\text { pesanan ke } \\
\text { pengunjung } \\
\text { dan } \\
\text { membersihka } \\
\text { n meja serta } \\
\text { membawa } \\
\text { peralatan } \\
\text { makan kotor } \\
\text { ke dapur } \\
\text { basah }\end{array}$} & 1 & 8 & $\begin{array}{l}11: 00-16: 0 \\
0\end{array}$ \\
\hline & & 2 & 8 & $\begin{array}{l}16: 00-21: 0 \\
0\end{array}$ \\
\hline \multirow{2}{*}{$\begin{array}{l}\text { Toko } \\
\text { bahan } \\
\text { kuline } \\
r\end{array}$} & \multirow{2}{*}{$\begin{array}{l}\text { Menjaga dan } \\
\text { melayani } \\
\text { keperluan } \\
\text { pengunjung }\end{array}$} & 1 & 5 & $\begin{array}{l}11: 00-16: 0 \\
0\end{array}$ \\
\hline & & 2 & 5 & $\begin{array}{l}16: 00-21: 0 \\
0\end{array}$ \\
\hline
\end{tabular}

Sumber: Penulis

Berikut ini aktivitas, pola aktivitas dan kebutuhan ruang pelayan:

Tabel 10 Aktivitas, Pola Aktivitas dan Kebutuhan Ruang Pelayan

\begin{tabular}{|c|c|c|c|}
\hline $\begin{array}{l}\mathbf{N} \\
\mathbf{0}\end{array}$ & Aktivitas & Pola Aktivitas & $\begin{array}{l}\text { Kebutuhan } \\
\text { Ruang }\end{array}$ \\
\hline 1 & Datang & \multirow{9}{*}{$1+2 \cdot \sqrt{3} \cdot \frac{4}{5} \cdot \sqrt{6} \cdot \frac{7}{8} \cdot \sqrt{2} \cdot \frac{6}{6}$} & \multirow{9}{*}{$\begin{array}{l}\text { Parkir, r. } \\
\text { loker, ATM } \\
\text { center, } \\
\text { dapur, area } \\
\text { pemesanan } \\
\text {, area } \\
\text { makan, } \\
\text { gudang } \\
\text { bahan, } \\
\text { toko bahan } \\
\text { kuliner, } \\
\text { galeri, } \\
\text { gudang, r. } \\
\text { genset, r. } \\
\text { pompa, } \\
\text { mushola } \\
\text { dan toilet }\end{array}$} \\
\hline 2 & Parkir & & \\
\hline 3 & Absen & & \\
\hline 4 & $\begin{array}{l}\text { Mengamanka } \\
\mathrm{n} \text { barang }\end{array}$ & & \\
\hline 5 & $\begin{array}{l}\text { Mengambil } \\
\text { uang }\end{array}$ & & \\
\hline 6 & $\begin{array}{l}\text { Menjalankan } \\
\text { tugas }\end{array}$ & & \\
\hline 7 & ishoma & & \\
\hline 8 & Buang air & & \\
\hline 9 & pulang & & \\
\hline
\end{tabular}

Sumber: Penulis

\section{Penjaga Parkir}

Penjaga parkir bertugas menjaga keamanan dan ketertiban area parkir di pusat kuliner. berikut ini pembagian, shift dan jam operasional penjaga parkir:

Tabel 11 Pembagian Penjaga Parkir

\begin{tabular}{|l|l|l|l|}
\hline Parkir & Shift & Jumlah Orang & Jam Operasional \\
\hline \multirow{2}{*}{ Motor } & 1 & 1 & $11: 00-16: 00$ \\
\cline { 2 - 4 } & 2 & 1 & $16: 00-21: 00$ \\
\hline \multirow{2}{*}{\begin{tabular}{l} 
dabil bus \\
\cline { 2 - 4 }
\end{tabular}} & 1 & 1 & $11: 00-16: 00$ \\
\cline { 2 - 4 } & 2 & 1 & $16: 00-21: 00$
\end{tabular}

Sumber: Penulis

Berikut aktivitas, pola aktivitas dan kebutuhan ruang penjaga parkir: 
Tabel 12 Aktivitas, Pola Aktivitas dan Kebutuhan Ruang Staf Keamanan

\begin{tabular}{|c|c|c|c|}
\hline $\begin{array}{l}\mathbf{N} \\
\mathbf{0}\end{array}$ & Aktivitas & Pola Aktivitas & $\begin{array}{l}\text { Kebutuhan } \\
\text { Ruang }\end{array}$ \\
\hline 1 & Datang & \multirow{9}{*}{$\left(1 \cdot 2 \cdot 3 \cdot \frac{4}{5} \cdot 6 \cdot \frac{7}{8} \cdot 2 \cdot 1\right.$} & \multirow{9}{*}{$\begin{array}{l}\text { Parkir, r. } \\
\text { loker, ATM } \\
\text { center, } \\
\text { mushola, } \\
\text { pos jaga } \\
\text { dan toilet }\end{array}$} \\
\hline 2 & Parkir & & \\
\hline 3 & Absen & & \\
\hline 4 & $\begin{array}{l}\text { Mengamanka } \\
\mathrm{n} \text { barang }\end{array}$ & & \\
\hline 5 & $\begin{array}{l}\text { Mengambil } \\
\text { uang }\end{array}$ & & \\
\hline 6 & $\begin{array}{l}\text { Menjalankan } \\
\text { tugas }\end{array}$ & & \\
\hline 7 & ishoma & & \\
\hline 8 & Buang air & & \\
\hline 9 & pulang & & \\
\hline
\end{tabular}

\section{Cleaning service}

Cleaning service merupakan orang yang ditugaskan untuk menjaga kebersihan bagian dalam maupun luar banguan pusat kuliner, cleaning service dibagi menjadi 2 yakni yang bertanggung jawab menjaga kebersihan area dalam bangunan pusat kuliner dan yang bertanggung jawab menjaga kebersihan area luar bangunan pusat kuliner yakni sebagai berikut:

Tabel 13 Pembagian Cleaning service

\begin{tabular}{|l|l|ll|}
\hline Cleaning service & $\begin{array}{l}\text { Jumlah } \\
\text { orang }\end{array}$ & Jam Operasional & \\
\hline Area Luar Bangunan & 2 & $09: 00-11: 00$ & \\
\hline Area Dalam Bangunan & 4 & $\begin{array}{lll}10: 00-11: 00 \\
16: 00-17: 00\end{array}$ & dan \\
& & & \\
\hline
\end{tabular}

\section{Sumber: Penulis}

Berikut aktivitas, pola aktivitas dan kebutuhan ruang cleaning service:

Tabel 14 Aktivitas, Pola Aktivitas dan Kebutuhan Ruang Cleaning service

\begin{tabular}{|c|c|c|c|}
\hline $\begin{array}{l}\mathbf{N} \\
\mathbf{0}\end{array}$ & Aktivitas & Pola Aktivitas & $\begin{array}{l}\text { Kebutuhan } \\
\text { Ruang }\end{array}$ \\
\hline 1 & Datang & \multirow{9}{*}{$\square \cdot 2 \cdot 3 \cdot \frac{4}{5} \cdot 6 \cdot \frac{7}{8} \cdot 2 \cdot$} & \multirow{9}{*}{$\begin{array}{l}\text { Parkir, r. } \\
\text { loker, ATM } \\
\text { center, } \\
\text { dapur, area } \\
\text { pemesanan, } \\
\text { r.tunggu, } \\
\text { area } \\
\text { makan, } \\
\text { kasir, } \\
\text { gudang } \\
\text { bahan, } \\
\text { toko bahan } \\
\text { kuliner, } \\
\text { galeri, area } \\
\text { hiburan, } \\
\text { gudang, r. } \\
\text { genset, r. } \\
\text { pompa, } \\
\text { mushola } \\
\text { dan toilet }\end{array}$} \\
\hline 2 & Parkir & & \\
\hline 3 & Absen & & \\
\hline 4 & $\begin{array}{l}\text { Mengamanka } \\
\mathrm{n} \text { barang }\end{array}$ & & \\
\hline 5 & $\begin{array}{l}\text { Mengambil } \\
\text { uang }\end{array}$ & & \\
\hline 6 & $\begin{array}{l}\text { Menjalankan } \\
\text { tugas }\end{array}$ & & \\
\hline 7 & ishoma & & \\
\hline 8 & Buang air & & \\
\hline 9 & pulang & & \\
\hline
\end{tabular}

Sumber: Penulis

\section{Pemain hiburan}

Pemain hiburan merupakan orang yang khusus menghibur para pengunjung pusat kuliner, berikut jenis hiburan dan jadwalnya serta aktivitasnya di dalam pusat kuliner:

Tabel 15 Jadwal Pemain Hiburan

\begin{tabular}{|l|l|l|l|}
\hline Hiburan & $\begin{array}{l}\text { Jumlah } \\
\text { pemain }\end{array}$ & Hari & Jam \\
\hline $\begin{array}{l}\text { Musik } \\
\text { panting }\end{array}$ & 5 & $\begin{array}{l}\text { Senin } \\
\text { Minggu }\end{array}$ & $13: 00-16: 00$ \\
\hline Madihin & 2 & Jumat & $18: 00-20: 00$ \\
\hline Lamut & 2 & Sabtu & $18: 00-20: 00$ \\
\hline Mamanda & 5 & Minggu & $18: 00-20: 00$ \\
\hline
\end{tabular}

Sumber: Penulis

Berikut ini aktivitas, pola aktivitas serta kebutuhan ruang pemain hiburan:

Tabel 16 Aktivitas, Pola Aktivitas dan

Kebutuhan Ruang Pemain Hiburan

\begin{tabular}{|c|c|c|c|c|}
\hline $\begin{array}{l}\mathbf{N} \\
\mathbf{O}\end{array}$ & Aktivitas & Pola Aktivitas & & $\begin{array}{l}\text { Kebutuhan } \\
\text { Ruang }\end{array}$ \\
\hline 1 & Datang & \multirow{9}{*}{$1+\sqrt{2} \cdot 3 \cdot \frac{4}{5} \cdot \sqrt{6}$} & \multirow{9}{*}{$+\frac{7}{8} \cdot 2 \cdot$} & \multirow{9}{*}{$\begin{array}{l}\text { Parkir, r. } \\
\text { loker, ATM } \\
\text { center, } \\
\text { area } \\
\text { hiburan, } \\
\text { mushola } \\
\text { dan toilet }\end{array}$} \\
\hline 2 & Parkir & & & \\
\hline 3 & Absen & & & \\
\hline 4 & $\begin{array}{l}\text { Mengamanka } \\
\mathrm{n} \text { barang }\end{array}$ & & & \\
\hline 5 & $\begin{array}{l}\text { Mengambil } \\
\text { uang }\end{array}$ & & & \\
\hline 6 & $\begin{array}{l}\text { Menjalankan } \\
\text { tugas }\end{array}$ & & & \\
\hline 7 & ishoma & & & \\
\hline 8 & Buang air & & & \\
\hline 9 & pulang & & & \\
\hline
\end{tabular}

Sumber: Penulis

\section{Pengunjung}

Pengunjung merupakan orang-orang yang datang ke pusat kuliner untuk menikmati kuliner dan fasilitas yang disediakan di pusat kuliner. Pengunjung terdiri dari pria dan perempuan yang berasal dari semua kalangan dan tingkatan umur, berikut kapasitas pengunjung yang dapat ditampung pusat kuliner:

Tabel 17 Kapasitas Pengunjung

\begin{tabular}{|c|c|c|c|}
\hline Fasilitas & keterangan & $\begin{array}{l}\text { Kapasitas } \\
\text { orang }\end{array}$ & $\begin{array}{l}\text { Jam } \\
\text { Operasional }\end{array}$ \\
\hline \multirow[t]{4}{*}{$\begin{array}{l}\text { Area } \\
\text { makan }\end{array}$} & $\begin{array}{lr}10 & \text { meja } \\
\text { kapasitas } & 4 \text { kursi }\end{array}$ & 40 orang & \\
\hline & $\begin{array}{l}5 \text { meja kapasitas } \\
4 \text { kursi }\end{array}$ & 30 orang & \\
\hline & $\begin{array}{l}5 \text { meja lesehan } \\
\text { kapasitas } 4 \\
\text { bantalan duduk }\end{array}$ & 20 orang & \\
\hline & $\begin{array}{l}4 \text { meja lesehan } \\
\text { kapasitas } 6 \\
\text { bantalan duduk }\end{array}$ & 24 orang & $11: 00-21: 00$ \\
\hline
\end{tabular}




\begin{tabular}{|c|c|c|}
\hline Galeri & $\begin{array}{l}\text { Menampung } \\
\text { orang yang } \\
\text { melihat-lihat } \\
\text { spot-spot galeri }\end{array}$ & 20 orang \\
\hline $\begin{array}{l}\text { Toko } \\
\text { bahan } \\
\text { kuliner }\end{array}$ & $\begin{array}{l}1 \text { retail ikan } \\
\text { haruan } \text { (ikan } \\
\text { gabus), } 1 \text { retail } \\
\text { beras ketan, } 1 \\
\text { retail bahan } \\
\text { media } \\
\begin{array}{l}\text { pembuatan, } 2 \\
\text { retail bumbu } \\
\text { dan rempah }\end{array}\end{array}$ & 50 orang \\
\hline \multicolumn{2}{|l|}{ Jumlah } & 184 orang \\
\hline
\end{tabular}

Sumber: Penulis

Berikut aktivitas, pola aktivitas dan kebutuhan ruang pengunjung di pusat kuliner:

Tabel 199 Aspek Atmospheres Peter Zumthor Aspek $\quad$ Penjelasan

The Body of Arsitektur dianggap sebagai sebuah tubuh Architecture yang terdiri dari bagian terlihat (kulit dan organ tubuh) dan bagian yang tidak terlihat (istem anatomi sel-sel di dalam tubuh).

Material $\quad$ diperlukan kepekaan yang kuat terhadap Compatibility material. Setiap materi memiliki keunikan tersendiri, material yang berbeda dapat dikolaborasikan sehingga meskipun saling bertolak belakang antara yang satu dan yang lain namun bisa tetap saling menunjang. Material yang digunakan bisa mempunyai sifat berkelanjutan dan fleksibel sehingga tak ada batasan dalam menggunakan dan mengolah material tersebut.

The Sound of $A$ Sebuah banguanan dianggap memiliki nada Space $\quad$ atau irama pada ruang-ruang yang dibentuk dan interior menjadi sebuah alat atau instrumen pembentuk suaranya, hal tersebut berkaitan dengan bentuk maupun permukaan ruang atau penggunaan material yang ada.

Tabel 18 Aktivitas, Pola Aktivitas dan Kebutuhan Ruang Pengunjung

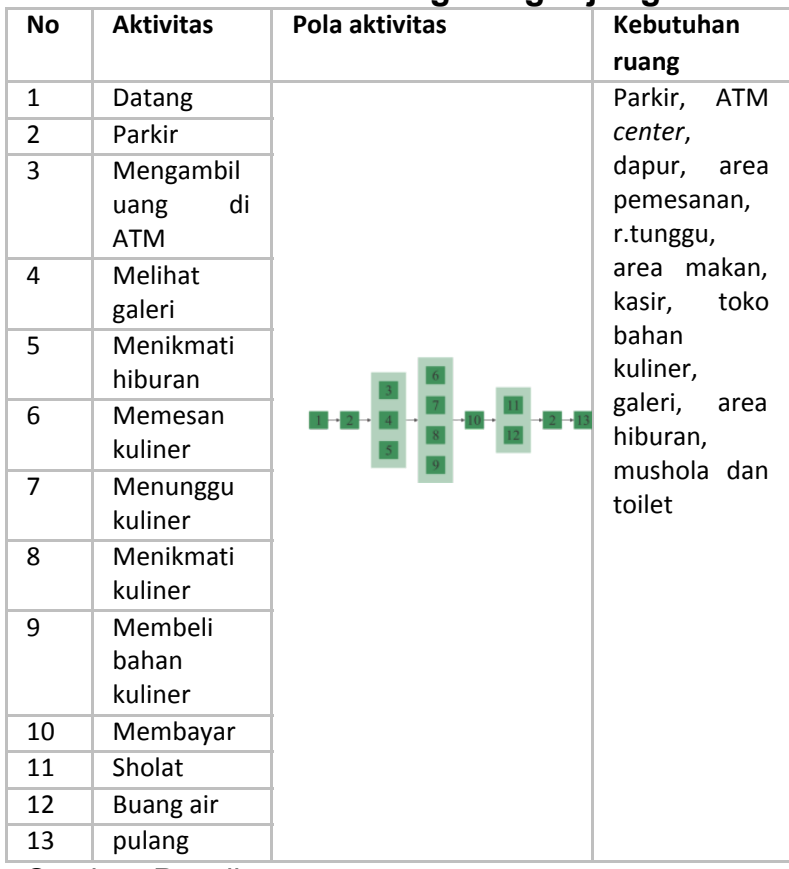

Sumber: Penulis

\section{A. Sembilan Aspek Atmospheres Peter Zumthor}

Pusat kuliner khas Hulu Sungai Selatan menggunakan konsep 9 aspek atmospheres Peter Zumthor yang menjadi parameter untuk menciptakan atmosfer pada desain ruang dan bentuk bangunan. Berikut tabel 9 aspek atmospheres Peter Zumthor serta penjabarannya:
The

Temperature of Space

temperature terdiri dari 2 bagian yakni temperatur fisik berupa pengaruh material yang digunakan dan temperatur psikis yakni bagaimana mengolah suasana atau keadaan dalam suatu ruang untuk mempengaruhi mood atau feeling dari orang-orang yang menggunakan atau berada dalam ruang tersebut.

Surrounding $\quad$ berbicara tentang apa saja yang ada di Objects $\quad$ sekeliling bangunan atau ruang dan manusia ataupun benda-benda yang dapat membangkitkan sebuah suasana, imajinasi, keindahan serta ketertarikan pada bangunan atau ruang tersebut.

\begin{tabular}{l|l} 
Between & ruang dan bangunan menjadi suatu pengarah
\end{tabular} Composure perilaku yang mana keberadaan bentuk, And Seduction ruang atau apapun dari sebuah bangunan memiliki pergerakan, alur atau urutan yang secara tidak langsung bersifat menuntun, menstimulasi dan memberi relaksasi agar setiap orang dapat berinteraksi dengan bangunan.

\begin{tabular}{l|l} 
Tension & Interior dan eksterior memiliki sifat dan fungsi
\end{tabular} Between berbeda namun saling mengikat. perlakuan Interior \& pada interior maupun eksterior dapat Exterior membangun sebuah karakter pada bangunan yang didesain misalnya bukaan-bukaan dapat mempengaruhi fasad bangunan yang secara tidak langsung dapat mengekspresikan karakter bangunan yang didesain.

Levels Of berkaitan dengan ukuran, skala serta dimensi Intimacy dari bentuk, ruang atau bukaan pada sebuah bangunan yang didesain, hal itu menjadi faktor bangunan seolah memiliki alur cerita di dalamnya.

The Light On Aspek ini menganggap sebuah bangunan Things merupakan masa murni bayangan yang kemudian diberikan cahaya dalam hal ini cahaya yang dimaksud adalah cahaya alami dan cahaya buatan yang nantinya dapat memberikan efek tersendiri pada ruang atau bangunan dan mempengaruhi kualitas spiritual pada sebuah ruang atau bangunan yang didesain.

Sumber: Jean S. P Langi \& Alvin J Tinangon 


\section{METODE}

Tujuan dibuatnya pusat kuliner khas hulu sungai selatan di Banjarmasin ini adalah untuk mengenalkan dan mempopulerkan kuliner khas Hulu Sungai Selatan, untuk mencapai tujuan itu maka pusat kuliner harus memiliki daya tarik pada bagian dalam maupun luar bangunannya sehingga pengunjung tertarik untuk datang dan mengenal kuliner khas Hulu Sungai Selatan dan kemudian merekomendasikan pusat kuliner ini kepada orang lain untuk ikut juga menikmati serta mengenal kuliner khas Hulu Sungai Selatan. Pengolahan bagian dalam dan luar pusat kuliner bisa dilakukan dengan metode atmospheres Peter Zumthor.

Metode atmospheres Peter Zumthor merupakan metode yang menggunakan pendekatan pengalaman sensori pada setiap objek arsitektural yang dirancang. Peter Zumthor memiliki konteksnya tersendiri dalam mendesain yakni dengan meninjau atau mempertimbangkan lebih dulu hal-hal yang tidak terlihat dalam hal ini berupa pengalaman sensori terhadap sebuah desain yang dirancang untuk menciptakan sebuah hal yang terlihat yakni banguanan yang memiliki kualitas serta daya tariknya tersendiri. dalam berarsitektur Peter Zumthor menekankan bahwa arsitektur itu tidak hanya terbatas pada hal-hal yang kasat mata tapi juga pada sense dan presence pada bangunan arsitektural yang didesain sehingga desain arsitektural tersebut dapat mempengaruhi siapapun yang terlibat, menikmati serta melihatnya.

Pada setiap karyanya Peter Zumthor memasukkan unsur-unsur kepekaannya dalam berarsitektur, hal itu tertuang ke dalam 9 aspek yang dijadikan parameter untuk menciptakan atmosfer pada desain ruang dan bentuk banguanan.

\section{PEMBAHASAN}

\section{A. Lokasi}

Lokasi tapak berada di jl. A. Yani Kec. Banjarmasin Tengah, kota Banjarmasin, km. 4,6 dengan aturan $\mathrm{KDB}: 60 \%, \mathrm{KDH}: 30 \%$ dan GSB: 35M dari as jalan. Luas total tapak adalah $4.597 \mathrm{~m}^{2}$ dengan jenis tanah rawa dan tidak berkontur

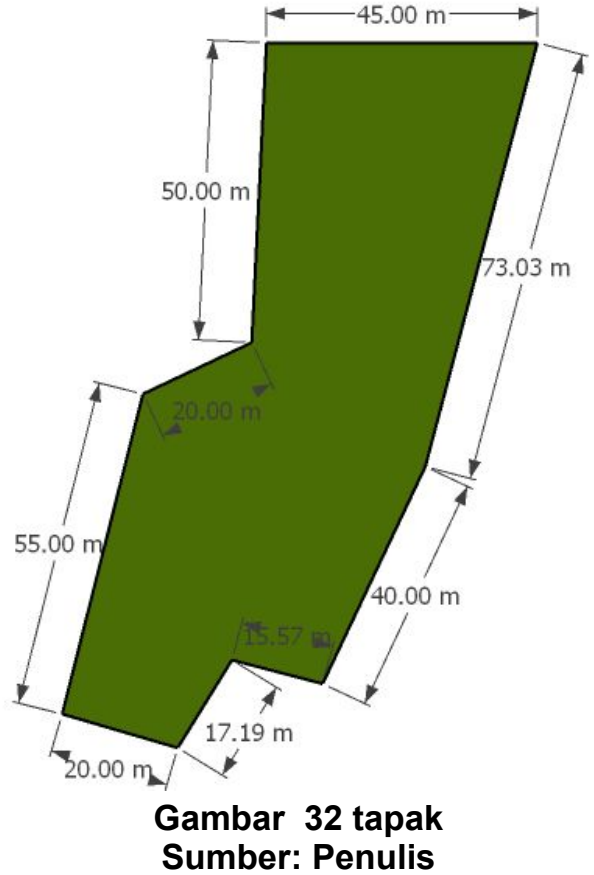

Batasan pada depan tapak ada rumah sakit ulin, pada samping kanan tapak ada toko dan hotel gplden tulip, pada samping kiri tapak ada toko dan pada bagian belakang tapak terdapat perumahan warga.

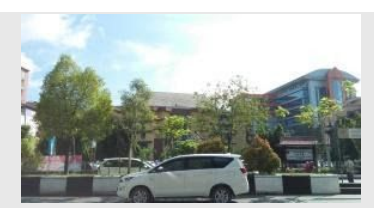

Gambar 33 Depan Tapak Sumber: dokumentasi dan survei

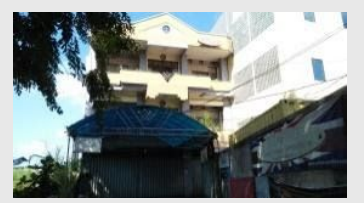

Gambar 35

Samping Kiri Tapak Sumber:

dokumentasi dan survei

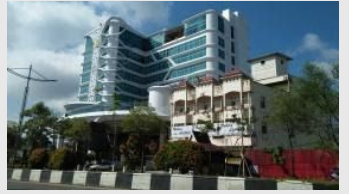

Gambar 34

Samping Kanan Tapak

Sumber: dokumentasi dan survei

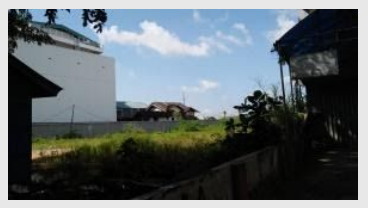

Gambar 36

Belakang Tapak Sumber:

dokumentasi dan survei
Tapak ini dipilih karena beberapa

kelebihan yang dimiliki yakni:

- Lokasi mudah dicapai dan tepat berada di pinggir jl. A. yani km. 4,6.

- Di sekitaran tapak terdapat banyak hotel dan fasilitas komersial yang digunakan banyak orang yang singgah atau menetap di Banjarmasin. 
- Berada di pinggir jalan utama yang pasti dilalui oleh semua orang yang memasuki kota Banjarmasin..

- Berada di kawasan komersial yang sesuai dengan fungsi dari pusat kuliner

- Memiliki luas yang cukup yakni 4.597 $\mathrm{m}^{2}$.

- Berada di tengah kota sehingga berpotensi menarik banyak pengunjung.

- Memiliki ketersediaan air bersih, listrik dan riol kota yang baik.

\section{B. Konsep Programatik}

Seperti yang sudah disebutkan sebelumnya pusat kuliner khas Hulu Sungai Selatan ini bertujuan untuk mempopulerkan kuliner khas kepada semua lapisan masyarakat dari berbagai daerah untuk itu maka diperlukan media yang baik untuk dapat menarik orang-orang menyambangi pusat kuliner khas Hulu Sungai Selatan ini yaitu dengan menampilkan daya tarik yang khas dari bagian dalam maupun luar bangunannya. Dengan metode atmospheres Peter Zumthor dan aspek-aspeknya sebagai konsep untuk memunculkan daya tarik yang khas sehingga dapat menjadi media yang baik untuk mempopulerkan kuliner khas Hulu Sungai Selatan. Bagian yang mendapatkan penekanan oleh aspek-aspek atmospheres Peter Zumthor ini adalah bagian interior berupa area utama yakni dapur serta area makan dan area pendamping yakni galeri serta toko penjualan bahan, selain itu juga bagian eksterior yakni bagian luar bangunan dan pengolahan tapak. Berikut ini skema konsep program yang diterapkan:

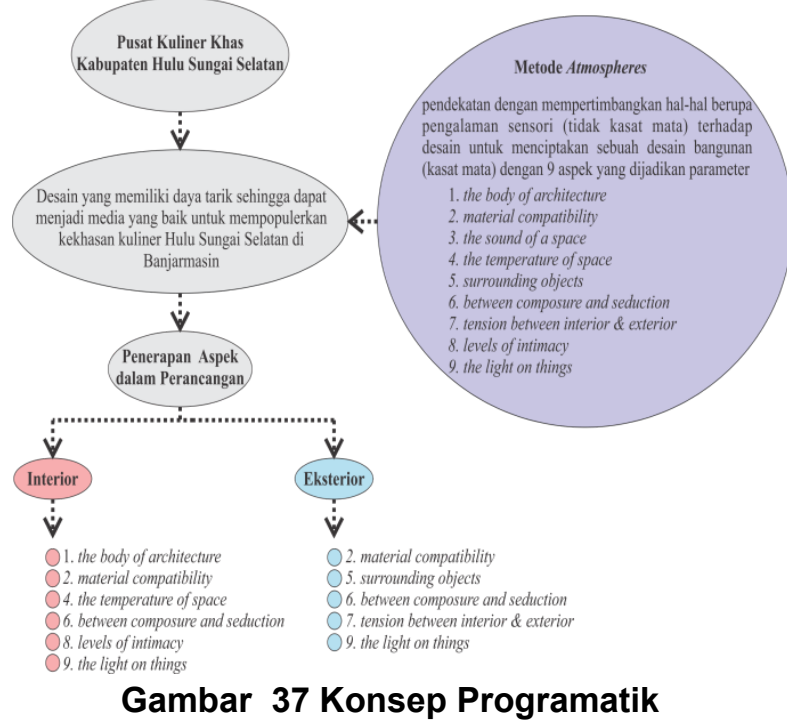

Gambar 37 Konsep Programatik

\section{Sumber: Analisis Penulis}

C. Konsep Skematik

1. Interior

- Area Makan

Tabel 20 Area Makan

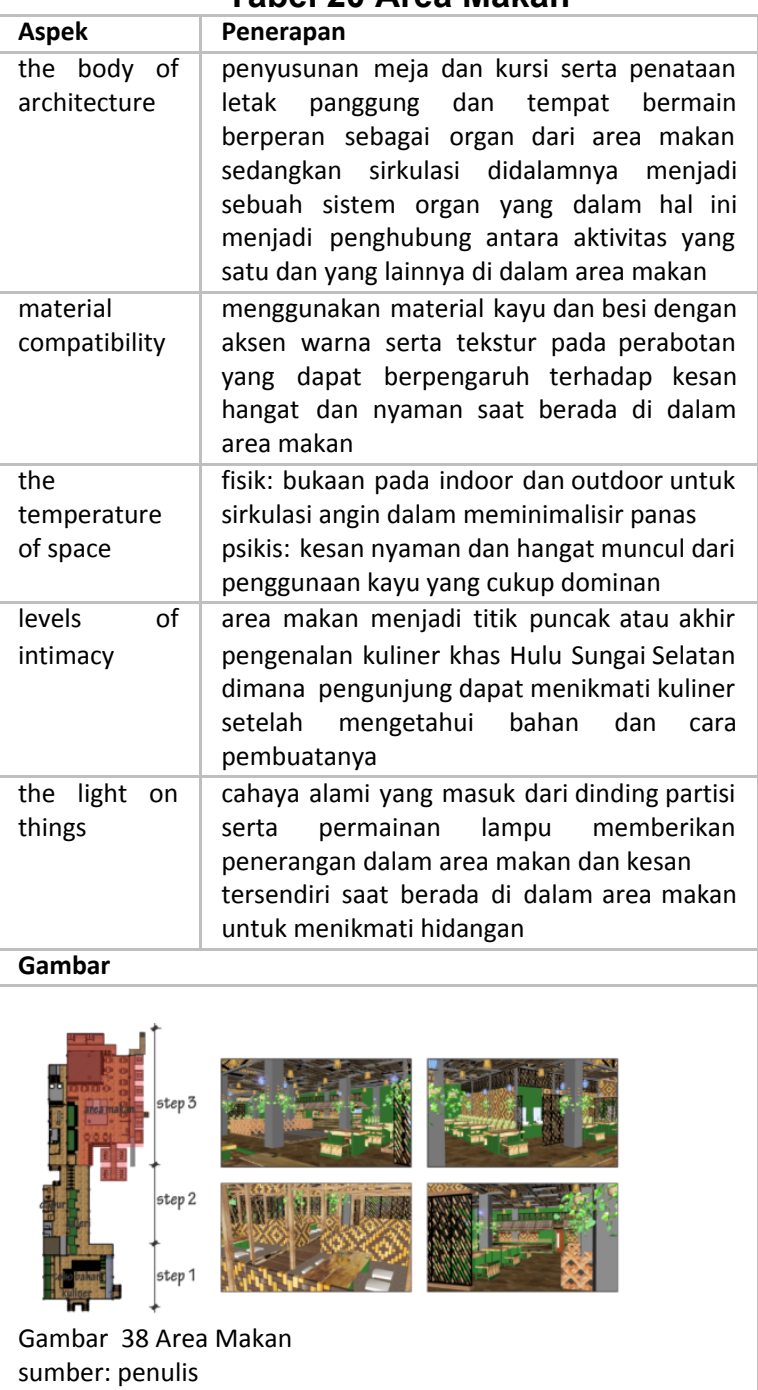

sumber: penulis

- Dapur

\begin{tabular}{|l|l|}
\hline Aspek & Penerapan \\
\hline the body of & $\begin{array}{l}\text { dapur yang dibagi menjadi beberapa bagian } \\
\text { membentuk organ yang kemudian ditata } \\
\text { peletakannya berdasarkan kebutuhan dan } \\
\text { runtutan proses penyajian kuliner } \\
\text { menciptakan sirkulasi yang menjadi sistem } \\
\text { organ dalam dapur }\end{array}$ \\
\hline $\begin{array}{l}\text { the } \\
\text { of space }\end{array}$ & $\begin{array}{l}\text { fisik: dibuat bukaan dan dinding partisi yang } \\
\text { tidak menghalangi sirkulasi udara keluar } \\
\text { masuk agar hawa panas pada saat proses } \\
\text { pengolahan atau pemasakan kuliner tidak } \\
\text { terkurung di dalam dapur }\end{array}$ \\
\hline $\begin{array}{l}\text { between } \\
\text { composure } \\
\text { and } \\
\text { seduction }\end{array}$ & $\begin{array}{l}\text { pergerakan di dalam dapur sesuai dengan } \\
\text { kebutuhan dan runtutan proses penyajian } \\
\text { kuliner(dapur penerimaan - gudang bahan } \\
\text { makanan - dapur pengolahan - } \\
\text { memasak - dapur penyajian - dapur basah) }\end{array}$ \\
\hline
\end{tabular}




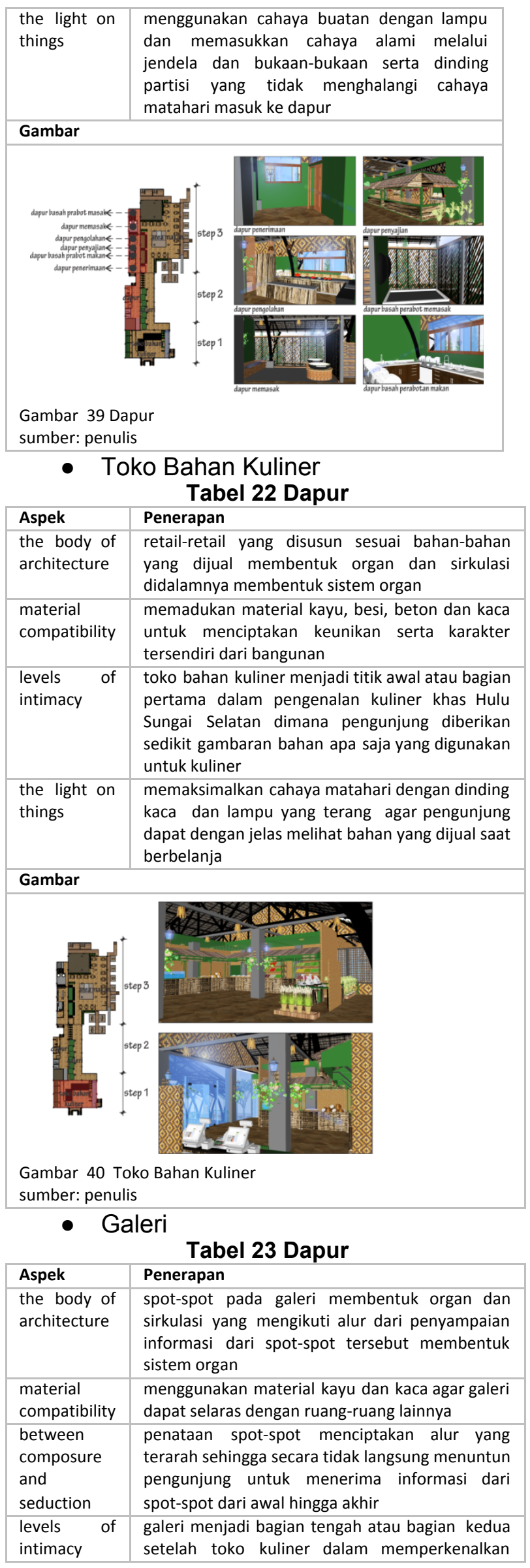

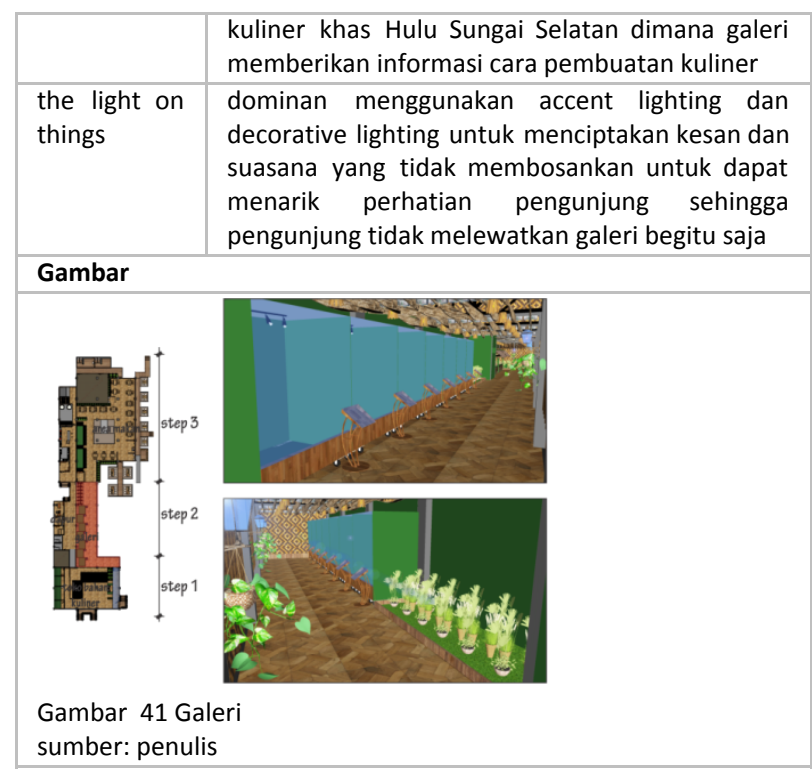

\section{Eksterior}

\begin{tabular}{|c|c|}
\hline Aspek & Penerapan \\
\hline $\begin{array}{l}\text { material } \\
\text { compatibilty }\end{array}$ & $\begin{array}{l}\text { perpaduan material kayu dan besi yang } \\
\text { dominan pada bangunan menciptakan } \\
\text { keunikan tersendiri pada bangunan jika } \\
\text { dilihat dari luar }\end{array}$ \\
\hline $\begin{array}{l}\text { surrounding } \\
\text { object }\end{array}$ & $\begin{array}{l}\text { tapak berada di kawasan komersial dengan } \\
\text { bangunan-bangunan berlantai cukup } \\
\text { banyak dengan gaya modern yang } \\
\text { dominan, hal ini dapat membuat pusat } \\
\text { kuliner menjadi bangunan yang menarik } \\
\text { dengan gaya bangunan yang berbeda dari } \\
\text { sekitarnya }\end{array}$ \\
\hline $\begin{array}{l}\text { between } \\
\text { composure and } \\
\text { seduction }\end{array}$ & $\begin{array}{l}\text { bagian tapak didesain dengan } \\
\text { mempertimbangkan orang, mobil, motor } \\
\text { dan bus yang digerakkan dengan membuat } \\
\text { pulau/taman serta pemilihan dan } \\
\text { peletakan pohon yang disesuaikan dengan } \\
\text { kebutuhan dan sirkulasi yang diperlukan }\end{array}$ \\
\hline $\begin{array}{l}\text { tension } \\
\text { between } \\
\text { interior } \\
\text { exterior }\end{array}$ & $\begin{array}{l}\text { karakter dari bangunan dapat tercipta dari } \\
\text { desain yang berbeda dari bangunan sekitar } \\
\text { serta perpaduan material yang dianggap } \\
\text { saling bertolak belakang secara kesan yakni } \\
\text { material kayu yang terkesan tradisional } \\
\text { dan besi yang terkesan modern }\end{array}$ \\
\hline $\begin{array}{l}\text { the light on } \\
\text { things }\end{array}$ & $\begin{array}{l}\text { penggunaan dan penataan general lighting } \\
\text { dan accent lighting pada tepat untuk } \\
\text { penerangan di malam hari }\end{array}$ \\
\hline
\end{tabular}

Gambar
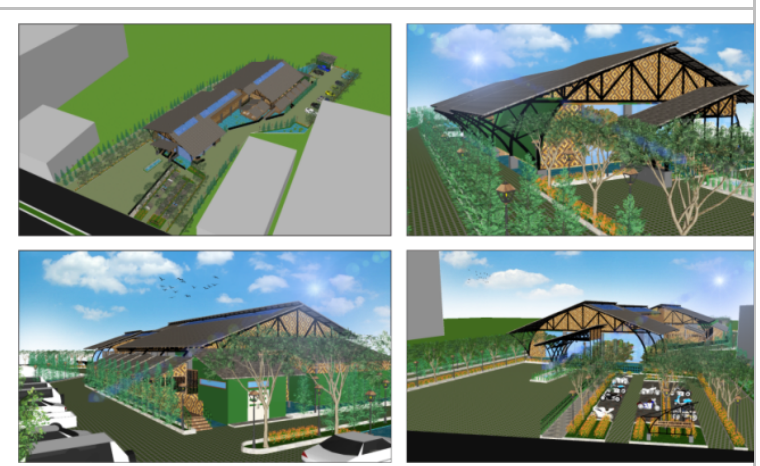

Gambar 42 Eksterior

sumber: penulis 


\section{KESIMPULAN}

Kuliner khas Hulu Sungai Selatan sebenarnya sudah ada di kota Banjarmasin namun sebagian besar yang dijual hanya kuliner ketupat kandangan saja, sedangkan kuliner khas Hulu Sungai Selatan yang lainnya kurang dipopulerkan di Banjarmasin selain itu tempat penjualan kuliner khas Hulu Sungai Selatan hanya menyediakan tempat makan dan parkir saja yang membuat pengunjung tidak dapat mengetahui bagaimana keunikan proses pembuatan atau pengolahan berbagai kuliner khas Hulu Sungai Selatan yang sebenarnya dapat menjadi strategi untuk menarik pengunjung sekaligus mengenalkan kekhasan kuliner Hulu Sungai Selatan. Maka dari itu di rencanakanlah Pusat Kuliner Khas Kabupaten Hulu Sungai Selatan yang berlokasi di jalan A. Yani dengan luas tapak $4.597 \mathrm{~m}^{2}$ yang memiliki aturan GSB $35 \mathrm{M}$ dari AS jalan, $\mathrm{KDH} 30 \%$ dan KDB $60 \%$.

Pusat kuliner ini bertujuan untuk mengenalkan dan mempopulerkan kekhasan kuliner Hulu Sungai Selatan kepada orang-orang yang datang dari luar pulau kalimantan, khususnya kepada orang-orang dari berbagai provinsi maupun kabupaten yang singgah atau menetap di Banjarmasin berupa pusat kuliner khas Hulu Sungai Selatan yang dapat mempermudah orang-orang untuk mencicipi, mengetahui dan mengenal kuliner khas Hulu Sungai Selatan. Untuk itu diperlukan pengolahan interior maupun eksterior pusat kuliner menggunakan metode atmospheres Peter Zumthor dengan aspek desain atmospheres Peter Zumthor sebagai konsep interior maupun eksterior pusat kuliner.

Pada bagian interior difokuskan pada pengolahan desain area utama yakni dapur serta area makan dan area pendamping yakni galeri serta toko penjualan bahan kuliner dan bagian eksterior difokuskan pada pengolahan desain bagian luar bangunan dan tapak. Dengan pengolahan desain interior dan eksterior pada pusat kuliner ini diharapkan nantinya pengunjung tidak hanya dimanjakan oleh cita rasa khas kuliner Hulu Sungai Selatan tetapi juga suasana, nuansa dan fasilitas yang tidak dapat ditemui di tempat lain sehingga pengunjung tertarik untuk datang lagi dan merekomendasikan pusat kuliner ini kepada orang lain, dengan begitu kuliner khas Hulu Sungai Selatan akan popular tidak hanya di kalangan orang Hulu Sungai Selatan tetapi juga di kalangan orang luar Hulu Sungai Selatan.

\section{DAFTAR PUSTAKA}

Atmadjaja, Jolanda Srisusana dan Meydian Sartika Dewi. 1999. Estetika Bentuk. Jakarta: Gunadarma

Evanindya, Fauzia.2011. Aroma Dalam Ruang Arsitektur. Fakultas Teknik. Universitas Indonesia. Depok

Kamus Besar Bahasa Indonesia edisi Kedua (1994:801)

Langi, Jean S. P \& Tinangon, Alvin J. 2012. Atmospheres - Parameter Desain Peter Zumthor Dalam Arsitektur. Vol. 1 No. 1. Jurusan Arsitektur, Fakultas Teknik Universitas Sam Ratulangi, Manado.

Nasihuddin, Achmad Agus. 2010. "Pusat Wisata Kuliner di Kabupaten Lamongan". Fakultas Sains dan Teknologi. Universitas Islam Negeri Maulana Malik Ibrahim. Malang

Neufert, Ernst.1996. Data Arsitek : Erlangga. Jakarta

Noor, Nisa Anasandi. 2016. "Pusat Kuliner Khas Banjar di Martapura”. Fakultas Teknik. Universitas Lambung Mangkurat. Banjarbaru

Wicaksono, A Andie dan Endah Tisnawati. 2014. Teori Interior. Jakarta: Griya Kreasi

KTO. 2016. 8 Cara untuk Bersenang-Senang di K-Style Hub!. https://www.visitKorea.or.id/article/8-ca ra-untuk-bersenang-senang-di-k-stylehub (diakses tanggal 18 maret 2019)

Paramitha, tasya. 2016. Belajar Membuat Kimchi di Pusat Kuliner Korea. https://www.viva.co.id/gaya-hidup/trave I/775068-belajar-membuat-kimchi-di-pu sat-kuliner-Korea (diakses tanggal 18 maret 2019)

Wikipedia. Lau Pa Sat. https://en.wikipedia.org/wiki/Lau_Pa_S at (diakses tanggal 19 maret 2019) 